\title{
Rural tourism development in mountain regions: Identifying success factors, challenges and potentials
}

\author{
Lena-Marie Lun, Harald Pechlaner and Michael Volgger*
}

\author{
Lena-Marie Lun \\ European Academy of Bozen/Bolzano, Institute for Regional Development and Location \\ Management, Viale Druso 1, 39100 Bolzano, Italy. \\ lenamarie.lun@eurac.edu \\ Harald Pechlaner \\ European Academy of Bozen/Bolzano, Institute for Regional Development and Location \\ Management, Viale Druso 1, 39100 Bolzano, Italy. \\ Catholic University of Eichstätt-Ingolstadt, Chair in Tourism, Pater-Philipp-Jeningen-Platz 2, \\ 85072 Eichstätt, Germany. \\ harald.pechlaner@eurac.edu \\ Michael Volgger \\ European Academy of Bozen/Bolzano, Institute for Regional Development and Location \\ Management, Viale Druso 1, 39100 Bolzano, Italy. \\ michael.volgger@eurac.edu
}

\section{Acknowledgements}

This research was funded by the European Commission (EACEA) within the 2012 Life Long Learning Programme (Transveral Programme, Key Activity 3) and conducted with the support of IMC University of Applied Sciences Krems, SOPHIA Research \& Innovation, Associazione Seed, UNEP Vienna, Bournemouth University, Romontana, Ecopsychology Society and Information Center Green Dossier.

* This is an author generated postprint version (with author's formatting) of the article: Lun, L.M., Pechlaner, H., \& Volgger, M. (2016). Rural tourism development in mountain regions: Identifying success factors, challenges and potentials. Journal of Quality Assurance in Hospitality \& Tourism, 17(4), 389-411. The Version of Record of this manuscript has been published and is available in the Journal of Quality Assurance in Hospitality \& Tourism 07/07/2016 (published online): http://www.tandfonline.com/10.1080/1528008X.2015.1096754 


\title{
Rural tourism development in mountain regions: Identifying success factors, challenges and potentials
}

\begin{abstract}
Rural tourism may act as an important driver for rural development in peripheral mountain communities that often face numerous economic, social and environmental challenges. In spite of their exceptional natural and cultural resources and heritage, they may have difficulties to take advantage of emerging dynamic processes.

The present study strives to identify key success factors, risks and potentials for the development of attractive tourism products and services within rural and mountain areas. It is based on semistructured, qualitative interviews with representatives of rural tourism best-practice initiatives across the Alps, the Apennines and the Carpathians, including case studies from Austria, Italy, Romania, Ukraine and Poland. With our analysis, we seek to contribute to the understanding of rural tourism development and management in mountain areas.

Findings indicate that the integration of agriculture and tourism greatly contributes to deliver authentic tourism experiences. Moreover, leadership, inter-sectoral networks, a common orientation towards quality, as well as effective communication seem to be key success factors to overcome potential obstacles in rural tourism development.
\end{abstract}

\section{Key words}

Rural tourism, mountain areas, success factors, SWOT, leadership. 


\section{Introduction}

Rural areas currently represent $52 \%$ of Europe's territory as well as $23 \%$ of its population (EU, 2013). Natural resource consumption and exploitation have long been the most important economic pillars of rural regions (Gartner, 2004). However, in the face of the continuous decline of the agricultural sectors' importance for rural economies, tourism research has increasingly paid attention to tourism's potential contribution to rural development (Sharpley and Sharpley, 1997). Sharpley and Roberts (2004) outlined that three main issues have been of fundamental relevance in the early stage of rural tourism research: issues of definition and conceptualisation, rural tourism as sustainable activity and rural tourism as an agent of rural development. Within our study, we focus on rural tourism as a driver of development processes in mountainous regions and thus also follow the rationale of the WTO (2004) that considers rural tourism to be important for promoting rural regional development, since it offers opportunities for generating income and creating employment possibilities. However, we also recognize that rural tourism development faces particular and challenging circumstances compared to urban destinations (OECD, 1994; Tsephe and Eyono Obono, 2013). Rural communities often find it difficult to benefit from emerging economic, social and environmental changes and may fail to take advantage of their own local resources and capabilities (Sharpley, 2002; George, Mair and Reid, 2009). Moreover, Mitchell and Hall (2005) identified several critical factors that rural tourism should meet in order to contribute to rural development processes and to the establishment of sustainable businesses: competition, marketing, cooperation and networking and, ultimately, globalisation.

Rural mountain communities are especially facing increasing challenges in terms of regional development (Godde, Price and Zimmermann, 2000); thus, many countries have integrated 
promotion of rural tourism into their regional and national development strategies in order to encourage economic diversification (Sharpley and Telfer, 2014). Although the extent to which this has been recognized on a policy level varies from country to country, the European Commission stated it as a priority in its 2007-2013 Rural Development Policy (EU, 2008).

However, for developing rural tourism there is still a need to understand the social, economic and environmental background of local rural communities (Devi, 2013). Moreover, Heberlein, Fredman and Vuorio (2002) argued that there are few comprehensive studies regarding tourism patterns in mountain regions and that most existing studies only focus on single case studies. Thus, mountain regions, being characterized by positive, as well as negative attributes in the context of rural tourism development (Nepal and Chipeniuk, 2005) seem to be particularly relevant for analysing rural tourism development.

Our study strives to close this gap by applying a multiple case study across different mountain regions that aims to identify common key success factors, as well as strengths, weaknesses, challenges and opportunities, which are crucial for developing rural tourism strategies and attractive products and offers within rural and mountain areas. Attractive tourism products in this context may be defined as products that succeed in fulfilling the customers' need for emotional experiences (Komppula, 2001). Moreover, previous studies suggested that the success of a destination essentially depends on the quality and range of the offered products, whereby the most attractive product is the one that best meets the customers' expectations (Avgousti, 2008). Based on a selection of best-practice case studies across five countries in the Alps, the Apennines and the Carpathians, the authors conducted qualitative interviews with representatives from these case studies in order to understand driving and limiting conditions for implementing rural tourism development, as well as to gain an insight into the strengths and weaknesses of such regions. 
"What we offer is authentic, therefore it is successful. We did not invent anything and we did not just reproduce something, we offer 'real situations'. Realities that evolved and have continuously developed in our community. This facilitates everything. We try to give the guests the opportunity to participate in these realities, which for us as community are normal, but for them could form [...] a memorable experience." (Member of a cooperative for the promotion of rural tourism, Italy; 2013, [translation])

The findings indicate that close-knit and inter-sectoral networks, a common orientation towards quality, as well as an effective communication and branding strategy seem to be key success factors for overcoming potential obstacles in rural tourism. The integration of agriculture and tourism contributes to delivering authentic tourism experiences, and to creating long-term positive effects in terms of well-being in rural communities. As a result, the unique characteristics of rural and mountainous areas can become success factors in the competition for national and international tourists.

\section{Literature Review}

Changing framework conditions and paradigms in rural environments confront many communities with the challenge of finding new sources of employment, income and means of sustaining their livelihoods. In this context, rural tourism is considered as an alternative for revitalizing communities. Relying on a rural region's natural and cultural resources, for instance the commonly beautiful and versatile landscape, and traditional lifestyle of the local people, rural tourism strives to provide visitors with the opportunity to immerse themselves in this heritage and experience it at first hand. 
Tourism literature has considered rural and mountain areas for at least the last 30 years and by the early 1990s, significant literature on the relationship between recreation, leisure and rural areas existed (Lane, 1993). Also, Sharpley and Roberts (2004) discussed the plethora of literature on the perceptions of rural tourism.

\section{Definition of rural tourism}

Definitions of rural tourism vary considerably and often the term is used synonymously with other expressions such as agritourism or ecotourism. The OECD (1994) defined rural tourism simply as all tourism activities that take place in sparsely populated countrysides. Another early and often cited definition of rural tourism was given by Lane (1994), who considered rural tourism as both located within rural areas and functionally rural. Thus, he described rural tourism activities as growing slowly, being traditional, as well as small-scale, and rooted within the local population. This publication is also considered to be the first attempt of constructing a theoretical framework regarding rural tourism as specific form of tourist activity (Sharpley and Roberts, 2004).

However, tourism research recognizes that rural tourism cannot be defined by simply putting it geographically in the countryside, since it comprises processes that are more complex (Lane, 2009). Rural tourism is often described as a form of tourism that meets the visitor's search for authenticity and individualism, as well as their increased wish to experience the local heritage and get into close contact with the population (Hall, Mitchell \& Roberts, 2003). The challenge of defining, or reaching a consensus on the definition of rural tourism is often ascribed to the underlying difficulty of defining rural itself (Page \& Getz, 1997). 


\section{Impacts of rural tourism and success factors}

Studies in the context of rural tourism touch on a wide range of themes; however, there has traditionally been a strong emphasis on its economic, social and environmental implications for local communities (Weaver, 1986; Bouquet \& Winter, 1987; Gartner, 1987; Butler \& Clark, 1992; Gannon, 1994; Oppermann, 1996; Page \& Getz, 1997; Sharpley, 2002). Rural tourism can not only improve and diversify the economic situation of local communities through new employment opportunities, but also support augmenting the visibility of a community and enhancing cultural opportunities (Weaver, 1986). Since rural tourism relies strongly on small local businesses, it is considered as a catalyst for generating a new entrepreneurial spirit (Okech, Haghiri \& George, 2012), which is identified as one of the most crucial driving forces underlying rural tourism development (Fotiadis, 2009).

Destination leadership (Pechlaner, Kozak \& Volgger, 2014) is an important boundary condition for rural tourism development. Rural tourism depends on leadership for developing successful cross-sector activities, and thus on local businesses that are inclined to take a calculated risk for the benefit of the whole destination (Haven-Tang and Jones, 2012). Some authors suggested that single entrepreneurs in a community are key actors in the process of developing a competitive rural tourism destination (Komppula, 2014), whereas others look at the multiple interrelations between destination leadership and rural tourism development (Pröbstl et al., 2014). The positive impacts of local networks in rural tourism development and their role as success factors are also considered (Cawley \& Gillmor, 2008). In her case study on integrated rural tourism, Cawley (2010) concluded that networks, especially informal ones between local businesses, were highly significant for adding value to the local community. Moreover, the importance of creating a Sense of Place, based on a region's cultural and social characteristics, has been analyzed (HavenTang \& Jones, 2005). 
However, tourism does not necessarily represent the best solution for rural development in all areas that need to enlarge their economic activities beyond agriculture or industry. Rural tourism might be characterized by "[...] income leakages, volatility, declining multipliers, low pay, imported labour and the conservatism of investors" (Butler \& Clark, 1992, p.175). Potentially negative impacts of rural tourism have been extensively discussed in the literature, and a substantial number of studies deal with sustainability in rural tourism (Bramwell, 1991; Lane, 1994b; Butler \& Hall, 1998; Gladstone \& Morris, 1998; Hall, Kirkpatrick \& Mitchell, 2005). Sustainability is claimed to constitute a crucial element in these development processes. Tourism behaviour is often at odds with the principles of sustainable tourism concepts (Sharpley, 2002), and rural destinations must carefully face eventual environmental, as well as economic and social challenges when engaging in tourism-based diversification of their economy.

\section{Rural tourism in a policy context}

In European countries, rural tourism mainly became an important issue since the 1990s and its promotion is becoming ever more significant. The European Strategic Guidelines for Rural Development assigns high priority to the aim of "Improving the quality of life in rural areas and encouraging diversification of the rural economy" (OJEU, 2006, p.26), specifically stating tourism as an important means of improving the competitiveness of rural areas.

Having become part of many countries' rural development policies, rural tourism is also frequently discussed from a governance point of view. This means researchers try to understand its complex role within the restructuring of the countryside, which is strategically driven by local, national and international policy makers (Page \& Getz, 1997; Nylander, 2001; Sharpley, 2002; Mair, 2006). Regarding rural tourism policy, it seems particularly important that quality management involves organization, products and offers (Williams, 2001; Skuras, Petrou \& 
Clark, 2006; Youell, 2003); this is considered to be a fundamental prerequisite for thriving rural tourism. Although many successful examples of rural tourism initiatives exist, some governments lack explicit rural tourism policies (Roberts \& Hall, 2001).

\section{Rural tourism in mountain areas}

Rural tourism is not only a field still exposed to a multitude of open questions in tourism research (Partalidou \& Iakovidou, 2008), but also one that needs further investigation to shed light on the challenging paths that communities face during its implementation. This is particularly relevant to the specific case of rural tourism in mountain areas (Heberlein, Fredman and Vuorio, 2002). Most rural tourism research refers to rural areas in general, or only implicitly focuses on mountain areas through case study selection. However, rural uplands and mountains forming diverse natural and cultural environments - characterize many of Europe's landscapes (Nordregio, 2004). Moreover, Nepal and Chipeniuk (2005) recognized that mountain areas are characterized by several unique elements, such as diversity, marginality, difficulty of access, fragility, niche and aesthetics, which due to their singularity have specific implications for tourism development. The precariousness of tourism development in mountain areas and the need for an integrated approach, which balances the needs of communities, tourists and the environment, are also extensively discussed by Godde, Price and Zimmermann (2000). Thus, mountain areas seem to be prototypical regions for analysing rural tourism development. On the one side, they are commonly endowed with a particular natural and cultural heritage making them ideal destinations for rural tourism, but on the other side, they also face particular challenges, such as accessibility, that makes tourism development challenging.

The economic impacts of various tourism forms on European rural mountain areas was analyzed by Snowdon, Slee \& Farr (2000). They found that tourism facilities in these areas were highly 
heterogeneous due the locations' different historical backgrounds and processes of tourism development. Moreover, especially in mountain areas "one needs an informed and active civil society, with strong non-governmental organizations and an independent and well-documented media" to oppose negative impacts of large-scale mass tourism projects (Valaoras, 1997, p.80).

\section{Methodology}

For this study, a qualitative research approach - based on the conduction of interviews and their analysis with GABEK (Zelger, 1994) - was chosen. Qualitative research is recognized as being suitable for providing "thick descriptions" and detailed accounts of complex phenomena (Wang, 2008; Gephart, R.P., 2004). Although the qualitative analysis method GABEK is still rather unknown on an international level (Pechlaner and Volgger, 2012), it has already been applied in several social science studies (Buber, 2004; Raich, 2008) as well as tourism related studies (Siller, Peters and Strobl, 2011; Pechlaner and Volgger, 2012). The research was supported by a steering group of European universities, as well as public-private and non-profit research and development associations. This group collectively gathered European best-practice case studies and identified eleven innovative examples in rural tourism, which are dispersed across different mountain ranges and which were perceived to be particularly successful examples of rural tourism development. The present study is based on empirical data deriving from semi-structured interviews with one representatives of each of these rural tourism best-practice initiatives across the Alps, the Apennines and the Carpathians, including case studies from Austria, Italy, Romania, Ukraine and Poland. The following table gives an overview regarding the conducted interviews. 
Table 1: Overview regarding the conducted interviews

\begin{tabular}{|c|c|c|c|c|}
\hline Country & Name of initiative & Description of the initiative & $\begin{array}{l}\text { Role of } \\
\text { interviewee }\end{array}$ & $\begin{array}{l}\text { Survey } \\
\text { administration }\end{array}$ \\
\hline \multirow{2}{*}{ Austria } & $\begin{array}{l}\text { 'Lechweg - Von der } \\
\text { Quelle bis zum Fall' }\end{array}$ & $\begin{array}{l}\text { First European trans-boundary long-distance hiking trail, an innovative product that was founded } \\
\text { by five tourism associations and which succeeded in increasing the attractiveness and } \\
\text { competitiveness of the destination. }\end{array}$ & Director & \multirow{2}{*}{ Telephone } \\
\hline & $\begin{array}{l}\text { 'Energie:autark' } \\
\text { Kötschach-Mauthen }\end{array}$ & $\begin{array}{l}\text { Association that was originally founded for the development of an energy self-sufficient } \\
\text { municipality and that gradually succeeded in establishing a tourism product based on the niche } \\
\text { topic of renewable energies. }\end{array}$ & Chairman & \\
\hline \multirow{5}{*}{ Italy } & $\begin{array}{l}\text { Albergo Diffuso } \\
\text { 'Borgo Sant'Angelo' }\end{array}$ & $\begin{array}{l}\text { Municipality that implemented the extraordinary "Albergo Diffuso" hospitality concept, which } \\
\text { has proven to be a successful model for developing tourism in peripheral areas and which has } \\
\text { resulted in economic, social and environmental returns for the local inhabitants. }\end{array}$ & Mayor & \multirow{3}{*}{ Telephone } \\
\hline & $\begin{array}{l}\text { Cooperativa 'I } \\
\text { Briganti di Cerreto' }\end{array}$ & $\begin{array}{l}\text { One of the first cooperatives in Italy that implemented community tourism and which succeeded } \\
\text { in re-qualifying the village and giving young local inhabitants a prospective to continue a living } \\
\text { in the area. }\end{array}$ & Ex-president & \\
\hline & $\begin{array}{l}\text { 'La Montagna } \\
\text { racconta' }\end{array}$ & $\begin{array}{l}\text { Mayor of a municipality, that together with its neighboring community, succeeded in valorizing } \\
\text { its unique historical heritage by creating a new and attractive tourism product based on the topic } \\
\text { of the First World War. }\end{array}$ & Mayor & \\
\hline & 'Marteller Beerental' & $\begin{array}{l}\text { Coordinator of a regional development cooperative that used a local agricultural product } \\
\text { (strawberries) for the creation of various tourism products, whereby the most important one is a } \\
\text { festival, which takes place every year and attracts a considerable number of tourists. }\end{array}$ & Coordinator & \multirow{2}{*}{ Face-to-face } \\
\hline & 'Wein.Kaltern' & $\begin{array}{l}\text { Director of an initiative - relating to the topic of wine - that was founded based on a common } \\
\text { vision of farmers, wine makers, tourism providers and other local actors and which has become } \\
\text { the central object of identification for both village inhabitants and tourists. }\end{array}$ & Director & \\
\hline \multirow{2}{*}{ Poland } & Agritourism 'Paryja' & $\begin{array}{l}\text { Owner of an agritourism facility that bases its activities on local natural resources and traditions } \\
\text { and which is a successful example of an entrepreneurial initiative that is environmentally, socially } \\
\text { and economically sustainable and which may serve as a role model for other local actors. }\end{array}$ & Owner & \multirow{2}{*}{ Telephone } \\
\hline & $\begin{array}{l}\text { Treasure Hunting } \\
\text { 'Questing' }\end{array}$ & $\begin{array}{l}\text { Initiator of a project that aims at the presentation of local cultural and natural heritage in an } \\
\text { innovative way, i.e. through a treasure hunt, and that succeeded in enriching the local tourist offer } \\
\text { as well as in being a low-cost possibility for the promotion of the region. }\end{array}$ & Initiator & \\
\hline Romania & $\begin{array}{l}\text { 'Bucovina } \\
\text { Adventure' }\end{array}$ & $\begin{array}{l}\text { Owner of a tour operating company that was founded to boost the local tourism offer of a } \\
\text { peripheral region based on outdoor sport activities and which succeeded in both, increasing the } \\
\text { competitiveness of the region and being a leadership business for other local tourism actors. }\end{array}$ & Owner & Telephone \\
\hline Ukraine & $\begin{array}{l}\text { Cheese Manufactory } \\
\text { 'Nizhne Selische' }\end{array}$ & $\begin{array}{l}\text { Initiator of a sustainable tourism product that is based on the cooperation between agriculture and } \\
\text { tourism and which succeeded in enhancing the image of the region as well as in improving the } \\
\text { local tourism infrastructure. }\end{array}$ & Initiator & Telephone \\
\hline
\end{tabular}

The 11 interviews were conducted between December 2013 and January 2014, either face-toface or via telephone and lasted between 30 and 45 minutes. Questions focused on success factors, strengths, weaknesses, challenges and opportunities in the context of rural tourism development.

The transcribed interviews were analyzed with GABEK (Zelger, 1994), a computer-aided method for evaluating unstructured qualitative data, which is based on the Gestalt theory of Stumpf (1939), as well as on the concept of creating linguistic Gestalts (Zelger, 1999). GABEK helps structure experiences, knowledge and perceptions of interviewees, and represents them in semantic networks of keywords (Zelger, 1999). The data analysis utilizing GABEK follows a 
strict and rigorous coding process that is recognized to comply with the rules of intersubjective traceability (Abfalter, 2010). Thus, the methodology - implemented with the software WinRelan - allows analyses that are objectively traceable, close to the original text data, and can be visually represented in user-friendly graphs (Buber \& Kraler, 2000). Moreover, Pechlaner \& Volgger (2012) suggested that the systematic approach of GABEK is an adequate method for evaluating complex phenomena and understanding causes and effects of certain processes. They furthermore introduced GABEK as an application, which offers a scarce opportunity for integrating a clearly structured analysis process with the advantage of qualitative approaches in dealing with complexity (Pechlaner \& Volgger, 2012).

In the first step of the analysis process, the data - the interviewees' opinions and perceptions are divided into coherent closed statements. In the second phase, the method requests selecting three to nine representative key words for each statement (Buber \& Kraler, 2000). Based on these coding steps, it is possible to build network graphs that display the identified keywords (Zelger et al., 2008). The results of our analysis are depicted through a particular type of network, called causal net graphs, showing positive and negative cause-and-effect relationships between keywords (Buber \& Kraler, 2000; Zelger et al., 2008).

The presentation of data is organized according to the SWOT framework, a concept first described by Learned et. al. (1969). The evaluation of qualitative data based on strengths, weaknesses, opportunities and threats has become a widely accepted strategic tool, since it allows the integration and synopsis of diverse information. 


\section{Discussion and results: Rural tourism in mountain areas - Success factors and SWOT analysis}

\subsection{Success factors}

When asked the reasons for succeeding in rural tourism development, the key words mentioned most frequently by the representatives of the mountainous best-practice case studies were recorded. Based on analysis of the interviews, we can identify six key clusters explaining success in rural tourism development (Fig. 1). To illustrate the analysis process, to make the results intersubjectively traceable and to enrich the higher-order clusters in figure 1 (success factors) with thicker descriptions (Geertz, 1973), the authors stated example citations for one of the keyword of every cluster in table 2 .

The case study representatives agreed that creating partnerships among local associations and businesses, establishing cross-border relationships, as well as collaborations with external consulting experts have all proven to be important for implementing rural tourism. In particular, cooperation between agriculture and tourism appears to be beneficial for destinations engaging in rural tourism. As food continues to be viewed as integral part of the tourist experience, the important link between agriculture and tourism for creating unique tourism experiences was emphasised in previous studies (Telfer and Wall, 1996; Hialager and Richards, 2002; Hall et al., 2003). Agricultural activity can be connected either directly, indirectly or passively with tourism, whereby a direct linkage indicates that agricultural activities (e.g. harvesting) are a tangible feature in the tourist product, an indirect linkage indicates that agricultural activities have only a secondary connection to the tourist experience (e.g. meal consumption, landscape protection, experience of traditions and authenticity) and ultimately, a passive linkage indicates that agriculture and tourism are two separate aspects only connected through the geographical 
location (Phillip, Hunter and Blackstock, 2010). However, agriculture, through its potential ability to convey authenticity, may be an essential component in the creation of tourism experiences (Phillip, Hunter and Blackstock, 2010). Nevertheless, Richards (2002) argued that the relationship between tourism and agriculture can also be characterized either by competition for land and labour or by a symbiosis, where both sectors benefit from each other. Richard (2002) also stated that due to the strong relationship between food and identity, it seems apparent that food plays an increasingly important role in tourism promotion.

Moreover, results suggest that a participative approach, involving the whole community in the decision-making processes, seems to be decisive for both generating long-term cross-sector relationships and rural tourism activities in general.

According to the interviewees, all products or services developed should comply with two fundamental criteria: quality and authenticity. Quality-based rural mountain tourism, built on a region's unique cultural and natural characteristics, provides visitors with an outstanding experience that encourages them to establish loyalty towards the destination. The concept of authenticity has already been introduced early in tourism research by Mac Cannell (1973), who argued that all tourists are in search for real, authentic experiences and since then, it has been extensively discussed (Wang, 1999). Sharpley (1994) explained, for example, that “[...] authenticity connotes traditional culture and origin, a sense of the genuine, the real or the unique" (Sharpley, 1994, p.130). Moreover, the concept of authenticity is strongly interrelated with the concept of experience in tourism (MacCannell, 1973; Cohen, 1979; Uriely, 2005; Volo, 2009). According to Pine II and Gilmore (1999), the interface between tourism and experience has become a fundamental focal point of tourism research. Moreover, O’Dell and Billing (2005) coined the term 'experiencescapes' to express the attempt of creating experiences at the amalgamation of tourism production and consumption and they have defined experiences as 
being "highly personal, subjectively, perceived, intangible, ever fleeting and continuously ongoing" (O’Dell and Billing, 2005, p.15). Defining experience quality in tourism may be rather difficult in practice, given that the nature of tourism is complex and is characterized by a multiplicity of participants and thus different interactions, expectations, attitudes and profiles (Jennings and Nickerson, 2006). Nevertheless, the UNWTO (2003) attempted to define quality in tourism as "[...] the result of a process which implies the satisfaction of all the legitimate product and service needs, requirements and expectations of the consumer, at an acceptable price, in conformity with $[\ldots]$ the underlying quality determinants such as safety and security, hygiene, accessibility, transparency, authenticity and harmony of the tourism activity [...].”

The development of rural tourism has to follow a clear organizational concept, as well as a funding scheme. Particularly in the beginning, as well as in mountainous areas, which are often structurally weak, financing by administrative institutions can be pertinent. However, this initial financial support often acts as a catalyst for entrepreneurial activities and private business initiatives that keep up financing in the long-term. Independently of who the pioneers in rural tourism development are (public administration, local businesses, etc.), leadership combined with visionary thinking and the willingness to take risks is needed.

Finally, the interviewees frequently admitted that up-to-date communication, involving modern ICT technologies and local, national and international media, is a core element in establishing a destination's image and its promotion, and thus for the long-term successful development of tourism in rural areas. 
Figure 1: Success factors in rural mountain tourism development

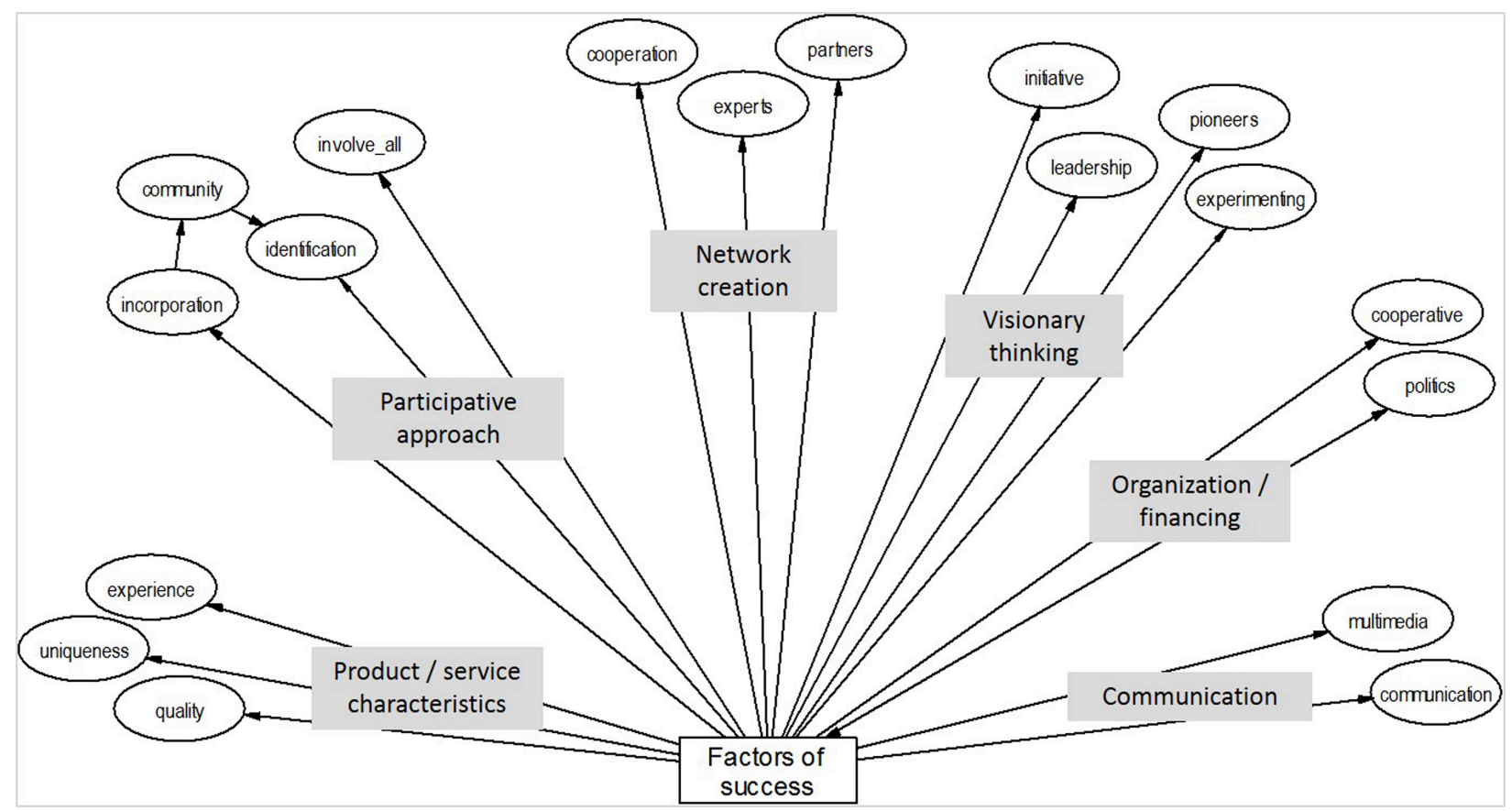

Note: A causal net graph with central key words mentioned by interviewees of the mountainous best-practice case studies regarding success factors in rural tourism. The key cluster words arising from the analysis were: product / service characteristics, participative approach, network creation, visionary thinking, organisation / financing, and communication. 
Table 2: Success factors - Example citations for one keyword of every cluster

\begin{tabular}{|c|c|c|c|c|}
\hline & Cluster & Keyword & Example citation & Interviewee \\
\hline & $\begin{array}{l}\text { Product/service } \\
\text { characteristics }\end{array}$ & Quality & $\begin{array}{l}\text { "From the beginning, quality } \\
\text { was a fundamental principle } \\
\text { underlying the event. We tried } \\
\text { to offer a different and a high- } \\
\text { quality experience." }\end{array}$ & $\begin{array}{l}\text { Regional } \\
\text { development } \\
\text { cooperative; Italy }\end{array}$ \\
\hline \multirow{5}{*}{$\begin{array}{l}\text { Factors of } \\
\text { Success }\end{array}$} & Participative approach & Involve_all & $\begin{array}{l}\text { "I think it was a good concept } \\
\text { that we aimed to involve } \\
\text { everybody, such as wine } \\
\text { producers, tourism operators, } \\
\text { public administration, opinion } \\
\text { leaders, etc. So everybody felt } \\
\text { involved." }\end{array}$ & $\begin{array}{l}\text { Tourism } \\
\text { association; Italy }\end{array}$ \\
\hline & Network creation & Cooperation & $\begin{array}{l}\text { "Cooperations played a } \\
\text { fundamental role, both within } \\
\text { the community as well as } \\
\text { beyond the community. We } \\
\text { always tried to seek out new } \\
\text { allies." }\end{array}$ & $\begin{array}{l}\text { Public } \\
\text { administration; } \\
\text { Austria }\end{array}$ \\
\hline & Visionary thinking & Initiative & $\begin{array}{l}\text { "The problem was that } \\
\text { everybody was laughing, } \\
\text { because nobody thought that } \\
\text { there could be made money } \\
\text { out of this. It needed } \\
\text { somebody to take the } \\
\text { leadership and then gradually } \\
\text { the attitude of the locals } \\
\text { improved." }\end{array}$ & $\begin{array}{l}\text { Tourism operator; } \\
\text { Romania }\end{array}$ \\
\hline & Organization/ financing & Cooperative & $\begin{array}{l}\text { "The organisation based on a } \\
\text { cooperative proved to be an } \\
\text { essential success factor. } \\
\text { Through the cooperative we } \\
\text { managed to finance } \\
\text { everything." }\end{array}$ & $\begin{array}{l}\text { Agricultural } \\
\text { cooperative; } \\
\text { Ukraine }\end{array}$ \\
\hline & Communication & Multimedia & $\begin{array}{l}\text { "Using modern information } \\
\text { and communication } \\
\text { technologies is very } \\
\text { important. Having a website } \\
\text { and a fan-page on Facebook is } \\
\text { crucial for promoting." }\end{array}$ & $\begin{array}{l}\text { Tourism operator; } \\
\text { Poland }\end{array}$ \\
\hline
\end{tabular}

\subsection{Strengths}

Rural tourism development is established upon identifying a region's strengths (Fig. 2), which, based on the aggregate of all different sectors - agriculture, gastronomy, sports, handicrafts, etc. - form the groundwork for developing tourism products. The tourism initiatives evaluated in this 
study were all build upon the pristine natural and cultural environments of their territory; in other words exceptionally beautiful, diverse and pristine natural landscapes, as well as rich cultural heritages. Both aspects should be considered equally; nevertheless it was suggested that especially in the context of conveying authenticity, a destination's cultural uniqueness - such as architectural style, traditional events, gastronomic specialties, etc. - plays an important role (Fig. 2). A sensible evaluation of both natural and cultural heritage, as well as giving visitors the opportunity to merge into this heritage, tends to lead to successful rural tourism development.

Moreover, our results suggest that rural mountain communities not only lack mass tourism and its negative impacts, but also reject this classic approach to tourism development, thus indicating commitment to a more sustainable form of tourism.

Figure 2: Strengths of rural mountain communities

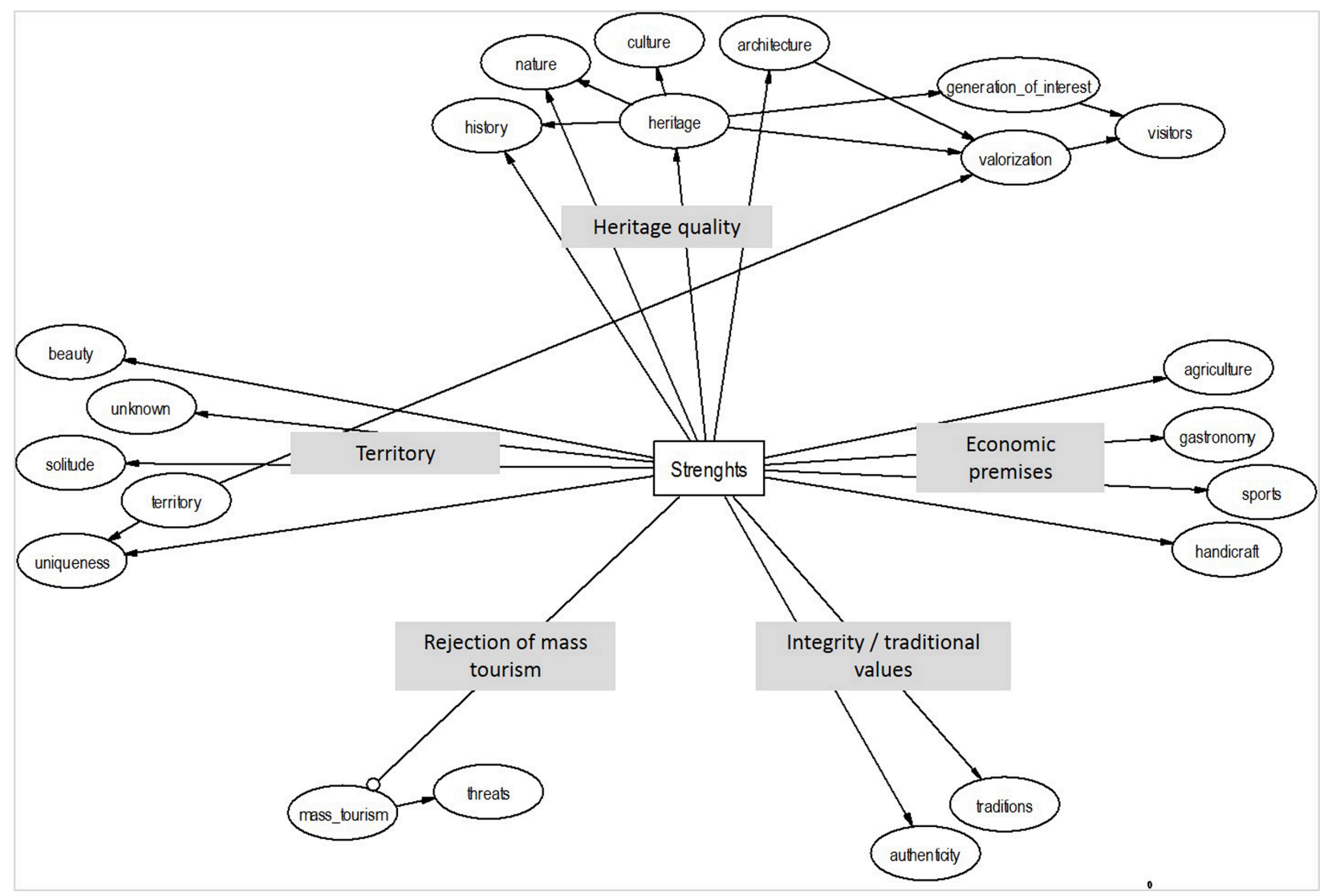


Note: The causal net graph of central key words mentioned by interviewees regarding principal strengths in the context of rural mountain tourism. The key cluster words arising from the analysis were: rejection of mass tourism, territory, heritage quality, economic fundament, and integrity / traditional values.

\subsection{Weaknesses}

Next to strengths, the interviewees were asked for the principal weaknesses of mountain communities in the context of rural tourism development to better understand the main driving forces for initiating tourism activities (Fig. 3). A traditional focus on agriculture and forestry, linked to reduced economic perspectives and high risk of unemployment often induce the need for alternatives and economic diversification. Moreover, many European mountainous areas are confronted with serious demographic changes, such as depopulation due to young people migrating away to urban regions in search of employment. Infrastructural problems were identified as a further typical weakness of peripheral uplands and mountains. This includes the lack of transport infrastructures, as well as the abandonment of long-standing historic infrastructures, such as settlements, mountain huts, etc., which are an essential part of the cultural heritage. Moreover, our results suggest that in some cases existing accommodation and services are lacking in quality, thus making it difficult to keep up in an ever more competitive global environment.

The geographical seclusion of many mountain areas is often considered both an advantage and a disadvantage for the development of rural tourism. Nevertheless, the lack of accessibility and visibility on an international, national and even regional tourism level was often stated as a point of criticism by the interviewees. Similarly, interviewees mentioned local administrative obstacles, such as bureaucracy and corruption, which impede efficient tourism development and enhancement.

Figure 3: Weaknesses of rural mountain communities 


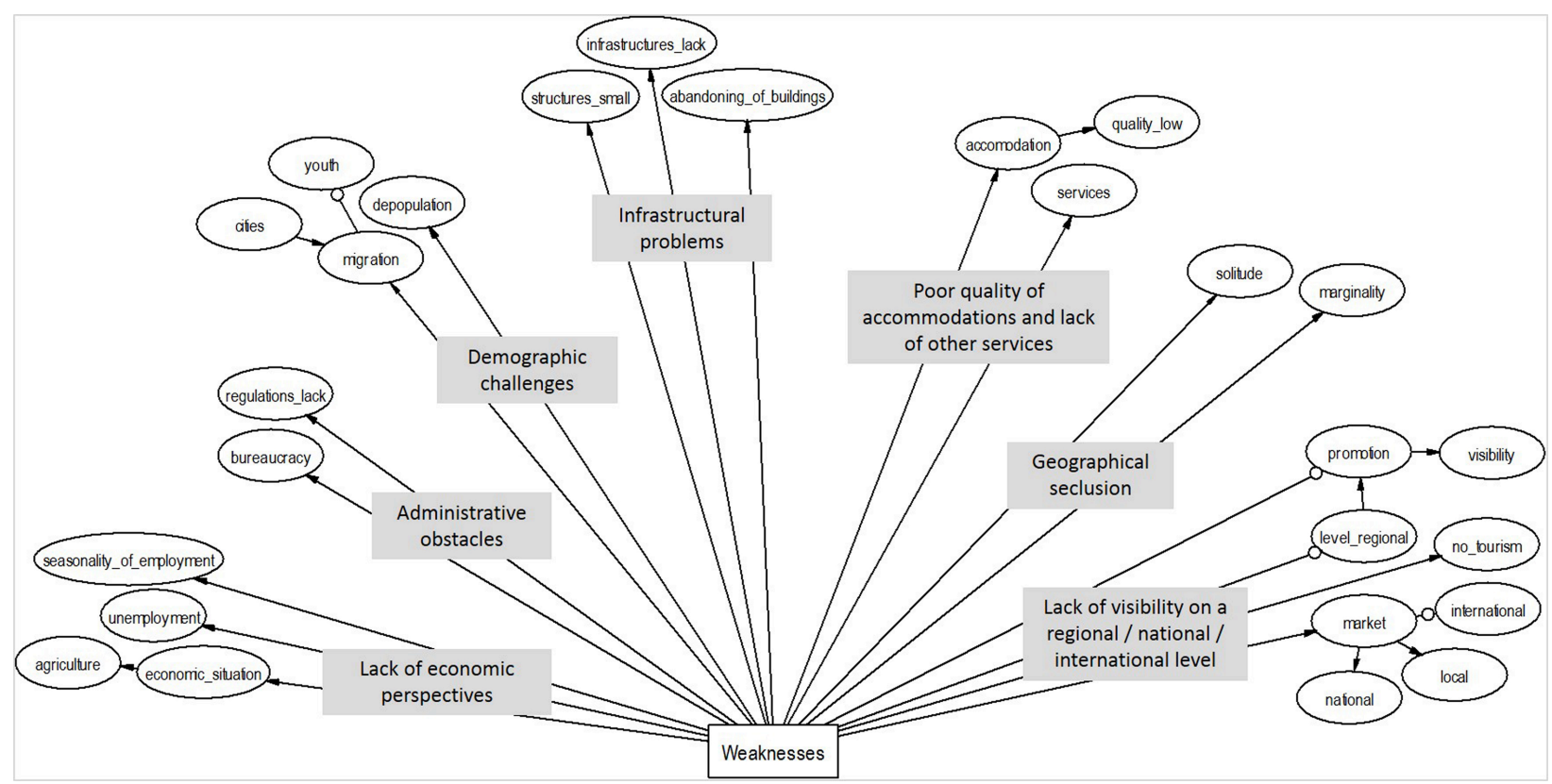

Note: The causal net graph of central key words mentioned by interviewees regarding principal weaknesses in the context of rural mountain tourism. The key cluster words arising from the analysis were: lack of economic perspectives, administrative obstacles, demographic challenges, infrastructural problems, poor quality of accommodation and lack of other services, geographical seclusion, and lack of visibility on a regional, national and international level.

\subsection{Challenges}

Rural mountainous areas not only face overall weaknesses related to their territory, but also must overcome specific challenges in the course of implementing rural tourism activities (Fig. 4). Our results suggest that creating acceptance among the local population is commonly one of the most sensitive topics. Generating interest for tourism is often difficult because low self-esteem about the touristic attractiveness of their region often prevails among local inhabitants ("This is not a tourism region anyway"). Interviewees suggested that initially the local people's attitude is often characterized by scepticism and mistrust, and that the process of creating understanding for rural tourism can be arduous and time-consuming, not least due to discrepancies of interests. Moreover, misunderstandings and disapproval arising from unclear allocation of competences 
and responsibilities from the outset are critical aspects. Integrating modern information and communication technologies - including social media - for distributing products and services, as well as for promoting a destination to the outside, is an essential aspect to be considered in rural tourism processes. Finally, a key challenge to overcome is often the lack of administrative support on the political level, since according to the interviewees this remains one of the most important initial driving forces for rural tourism development.

Figure 4: Challenges for implementing tourism in rural mountain communities

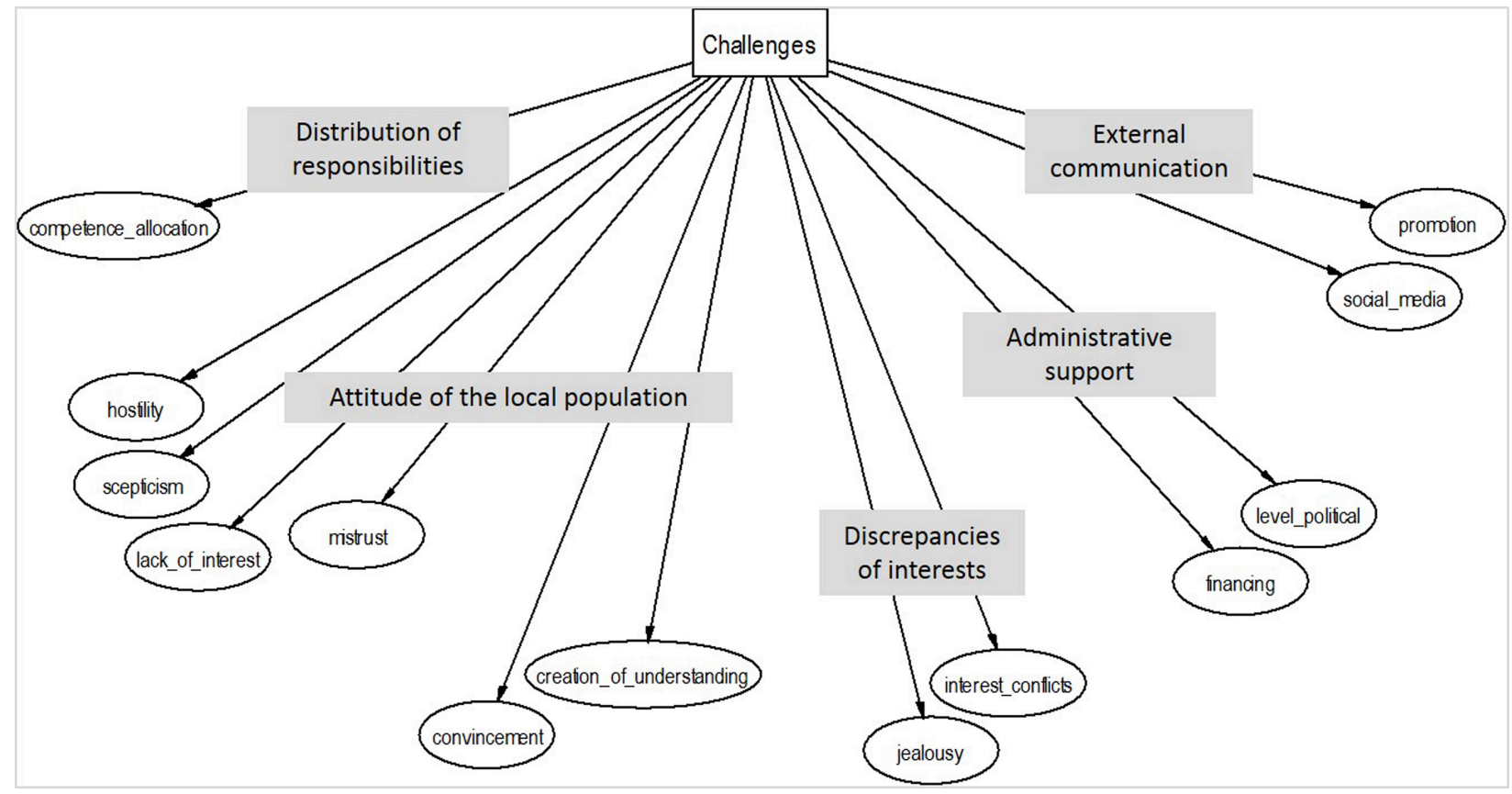

Note: The causal net graph of central key words mentioned by interviewees in the context of rural mountain tourism.

The key cluster words arising from the analysis were: distribution of responsibilities, attitude of the local population, discrepancies of interests, administrative support, and external communication.

\subsection{Opportunities}

Ultimately, we looked at possible long-term opportunities for mountain communities and rural tourism (Fig. 5). Communities previously dominated by agriculture that engage in tourism activities can enhance and diversify their economic situation. Through generating direct and indirect employment opportunities, rural tourism opens up new economic dimensions for the 
local people. Entrepreneurial activities may arise and local businesses come into existence over time. Successful rural tourism developments can lead to new vitality and dynamism within mountain communities that face the threat of economic and social decline. According to interviewees, the revitalization of communities is noticeable in new products and services that benefit visitors and inhabitants, and lead to architectural reconstructions, as well as changing patterns of demography.

Rural tourism development creates and strengthens regional economic cycles and generates synergies between different branches and businesses. It can be a catalyst for community innovation, thus promoting local entrepreneurship and improving the quality of life for the local population. Finally, rural tourism initiatives are a pathway to rediscovering a region and successfully positioning it as a tourism destination.

Figure 5: Rural tourism opportunities for mountain communities over the long-term

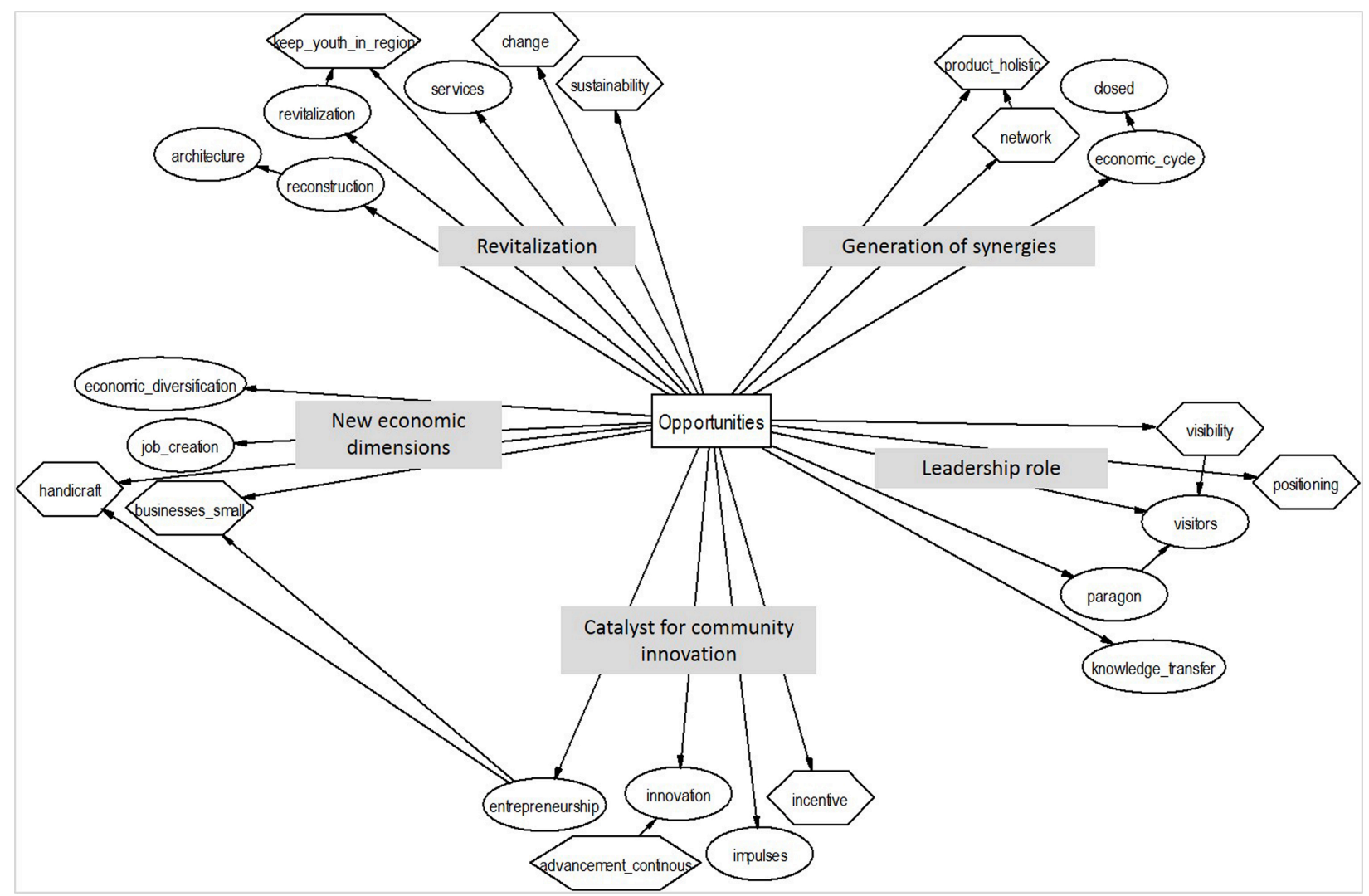


Note: The causal net graph of the central key words mentioned by the interviewees in terms of opportunities emerging from rural mountain tourism. The key cluster words arising from the analysis were: new economic dimensions, revitalization, generation of synergies, leadership role, and catalyst for innovation.

\section{Conclusion}

The analysis of the case studies shows that the success of rural tourism development in mountain areas often depends on a mix of general and idiosyncratic conditions. Each case has its peculiarities and characteristics that play a key role for its success. "La Montagna racconta", “"Energie:autark' Kötschach-Mauthen” and "Lechweg - Von der Quelle bis zum Fall” indicate that communities, which succeeded in being associated with a specific topic may develop attractive rural tourism products based on this topic. Such theme-based rural tourism development often involves trans-boundary cooperation as well. The case studies "Marteller Beerental", "Wein.Kaltern" and "Cheese Manufactory 'Nizhne Selische"” demonstrate that in regions, where a particular agricultural product is cultivated and processed, successful tourism activities may be created based on this product. In these approaches, cooperation between the agricultural and the tourism sectors is especially crucial.

The case studies "Cooperativa 'I Briganti di Cerreto"' and "Treasure Hunting 'Questing'“ indicate that a community approach to rural tourism development may be a potential path towards successful rural tourism offers, whereas the case studies "Agritourism 'Paryja", and "“Bucovina Adventure"” show that also single entrepreneurial initiatives can be the driver for rural tourism development. Ultimately, the case study "Albergo Diffuso 'Borgo Sant'Angelo"” is an example, where the public administration pushed the implementation of an innovative hospitality concept, which provided the basis for the development of rural tourism. 
Overall, our study offers an insight into common success factors as well as strengths, weaknesses, challenges and opportunities for rural mountain communities in the context of tourism development. Thus, it contributes to the understanding of rural tourism development, whose relationships and processes still need to be assessed critically (Hall, Roberts and Mitchell, 2003). Moreover, it offers a comparative analysis including case studies across several mountainous regions and thus it is specifically contributing to the better understanding of rural tourism in mountain areas - a tourism research field that is still dominated by the analysis of single case studies (Heberlein, Fredman and Vuorio, 2002). The study gives decision makers in rural mountain communities an insight into fundamental driving factors and problems that can be encountered in the promotion of rural tourism. Practitioners, such as decision makers in local governments, destination management organisations and tourism service providers of mountain communities, may consider the findings of this study relevant in the process of elaborating and implementing regionally adapted rural tourism strategies.

The findings of the study have shown that peripheral regions face numerous obstacles in the course of such a process. To overcome these, leadership seems crucial and is often provided by pioneers.
"We were catching the spirit of the age with our thematic positioning. Based on continuous awareness-raising we created an impulse for investment and innovation. [...] We took a certain leadership role; synergies have been created and now other municipalities have also started to incorporate this trend." (Member of an association for the promotion of rural tourism based on renewable energies, Austria; EURAC interviews, 2013, [translation])

In contrast to Komppula (2014), who assigned leadership predominantly to private entrepreneurs, the results of our study suggest that political or private-public associations can 
also take on leadership. Nevertheless, efforts undertaken by private local entrepreneurs are often the key to rural tourism development in communities where no destination management organizations exist, and convincing public administration is difficult.

The study suggests that leadership in rural tourism development seems to consist primarily of generating acceptance, creating cross-sectoral partnerships, establishing quality criteria, incorporating sustainability thinking, and creating a common vision. However, above all rural tourism pioneers must gain acceptance and commitment from the local population, as well as political support. Particularly for peripheral uplands and mountains, rural tourism represents an attractive opportunity to diversify economies that are traditionally characterized by agriculture and forestry.

Products developed at the interface of traditional sectors, e.g. agriculture, forestry and handicrafts, together with innovative entrepreneurial businesses, have especially shown potential to generate benefits for the whole community. Moreover, economic cycles that rely on local resources and cross-sectoral local partnerships appear to generate the most dynamic synergies in rural areas.

A tourism approach based on the specific natural and cultural patrimony of a region, and the subsequent creation of high quality products and services seem to be fundamental criteria for successful rural development. A clear organizational and financial structure - often based on destination management organizations and local administration - helps to establish thriving tourism processes. Rural tourism planning is most successful when it not only takes into consideration an economically, socially and environmentally sustainable vision for the whole community, but also strives to generate benefits for all community members involved.

Thus, the findings of the study support some of the assertions drawn from previously conducted studies, such as Weavers' (1986) suggestion that tourism can diversify local rural economies and 
increase their visibility. Moreover, it has shown the importance of rural tourism for community innovation, entrepreneurial spirit and destination leadership (Okech, Haghiri and George, 2012; Pechlaner, Kozak and Volgger, 2014). The findings emphasise the importance of emotionally integrating the natural and cultural patrimony of a region (Haven-Tang and Jones, 2005), creating local networks (Cawley and Gillmor, 2008) and of being explicitly supported by the local governments (Roberts and Hall, 2001).

Ultimately, the study also supports the results of Wilson et al. (2001), who suggested that success in rural tourism development is essentially determined by the entrepreneurial perspective, the community approach, place-orientation, leadership and cooperation and not only dependent on attractions, promotion, tourism infrastructure, services and hospitality (Gunn, 1988). Our multiple case study across several mountain ranges has also shown that next to infrastructure and marketing, governance aspects and entrepreneurship remain particularly crucial for rural tourism development in mountain areas.

\section{References}

Abfalter, D. (2010). Das Unmessbare messen? Die Konstruktion von Erfolg im Musiktheater. Dissertation Universität Innsbruck.

Avgousti, K. (2008). Assessment Issues Regarding Tourism Partnerships, Competitiveness and Sustainability: the Case of Cyprus. The Cyprus Journal of Sciences, 6, 169-180.

Bouquet, M., \& Winter, M. (1987). Who from their labours rest? Conflict and Practice in Rural Tourism. Aldershot: Avebury.

Bramwell, B. (1991). Sustainability and rural tourism policy in Britain. Tourism Recreation Research, 16(2), 49-51. 
Buber, R. (2004). The job image of young sales assistants: Introspection and young consumers' assessment. In J. Gadner, R. Buber \& L. Richards (Eds.) Organising knowledge: Methods and case studies (pp. 153-167). Houndmills, Basingstoke, Hamsphire: Palgrave Macmillan.

Buber, R., \& Kraler, C. (2000). How GABEK and WinRelan Support Qualitative Research. In R. Buber \& J. Zelger (Eds.), GABEK II. Zur Qualitativen Forschung. On Qualitative Research (pp. 111-137). Innsbruck, Wien, München: Studien-Verlag.

Butler, R., \& Clark, G. (1992). Tourism in rural areas: Canada and United Kingdom. In I. Bowler, C. Bryant \& M. Nellis (Eds.), Contemporary Rural Systems in Transition (Vol. 2, Economy and Society, pp. 166-186). Wallingford, Oxford: CAB International.

Butler, R.W., \& Hall, C.M. (1998). Conclusion: the sustainability of tourism and recreation in rural areas. In R.W. Butler, C.M. Hall \& J. Jenkins (Eds.) Tourism and Recreation in Rural Areas (pp. 249-258). Chichester: John Wiley and Sons.

Cawley, M. (2010). Adding value locally through integrated rural tourism: Lessons from Ireland. In G. Halseth, S. Markey \& D. Bruce (Eds.) The next rural economies (pp. 89-101). Oxfordshire: CABI.

Cawley, M., \& Gillmor, D. (2008). Integrated rural tourism: Concepts and practice. Annals of Tourism Research, 35(2), 316-337.

Cohen, E. (1979). A Phenomenology of Tourist Experiences. Sociology, 13(2), 179-201.

Devi, S. (2013). Rural Tourism: An effective key for the development of rural areas. In R.K. Miryala (Ed.) Changing paradigms of rural management (pp.321-332). Zenon Academic Publishing.

EU (2008). EU rural development policy 2007-2013. European Commission DirectorateGeneral for Agriculture and Rural Development. 
[http://enrd.ec.europa.eu/fms/pdf/BEC22A59-E570-413B-5A9B-682D3306E183.pdf]

EU (2013). Rural Development in the EU. Statistical and Economic Information. Report 2013.

European Commission, Directorate-General for Agriculture and Rural Development.

Fotiadis, A. (2009). The role of tourism in rural development through a comparative analysis of a Greek and a Hungarian rural tourism area. PhD Thesis, University of Pécs, Faculty of Business and Economics.

Gannon, A. (1994). Rural tourism as a factor in rural community economic development for economies in transition. Journal of Sustainable Tourism, 2(1-2), 51-60.

Gartner W.C. (1987). Environmental Impacts of Recreation Home Developments. Annals of tourism research, 14(1), 38-57.

Gartner W.C. (2005). A Perspective on Rural Tourism Development. The Journal of Regional Analysis and Policy, 35(1), 33-42.

Geertz, C. (1973). The interpretation of cultures. Selected essays by Clifford Geertz. New York: Basic Books, Inc., Publishers.

George, E.W., Mair H. \& Reid, D. (2009). Rural Tourism Development. Localism and Cultural Change. Tourism and Cultural Change, Vol. 17. Channel View Publications.

Gephart, R. P. (2004). Qualitative research and the Academy of Management Journal. Academy of Management Journal, 47(4), 454-462.

Gladstone, J., \& Morris, A. (1998). The role of farm tourism in the regeneration of rural Scotland. In D. Hall \& L. O’Hanlon (Eds.) Rural Tourism Management: Sustainable Options (pp. 207-221). Auchincruive: The Scottish Agricultural College.

Godde, P.M., Price, M.F. \& Zimmermann, F.M. (Eds.) (2000). Tourism and development in mountain regions. Wallingford, UK: CAB International.

Gunn, C. A. (1988). Tourism Planning. 2d ed. New York: Taylor and Francis. 
Haven-Tang, C., \& Jones, E. (2005). Using local food and drink to differentiate tourism destinations through a Sense of Place. The Journal of Culinary Science and Technology, 4(4), 69-86.

Haven-Tang, C., \& Jones, E. (2012). Local leadership for rural tourism development: A case study of Adventa, Monmouthshire, UK. Tourism Management Perspectives, 4, 28-35.

Hall, D., Kirkpatrick, I., \& Mitchell, M. (Eds.) (2005). Rural Tourism and Sustainable Business. Aspects of Tourism (Vol. 26). Clevedon, UK: Channel View Publications.

Hall, D., Mitchell, M., \& Roberts, L. (2003). Tourism and the Countryside: Dynamic Relationships. D. Hall, L. Roberts, \& M. Mitchell (Eds.) New Directions in Rural Tourism (pp. 3-18). London: Ashgate Publishing.

Hall, D., Roberts, L. \& Mitchell, M. (Eds.) (2003). New Directions in Rural Tourism. London: Ashgate Publishing.

Hall, C.M., Sharples, L., Mitchell, R., Macionis, N. \& Cambourne, B. (Eds.) (2003). Food Tourism Around the World. Taylor \& Francis.

Heberlein, T.A., Fredman, P. \& Vuorio, T. (2002). Current Tourism Patterns in the Swedish Mountain Region. Mountain Research and Development, 22(2), 142-149.

Hialager, A.M. \& Richards, G. (Eds.) (2002). Tourism and Gastronomy. London, New York: Routledge.

Jennings, G. \& Nickerson, N.P. (Eds.) (2006). Quality tourism experiences. Burlington, Oxford. Elsevier Butterworth-Heinemann.

Komppula, R. (2014). The role of individual entrepreneurs in the development of competitiveness for a rural tourism destination - A case study. Tourism Management, 40, 361-371. 
Komppula, R. (2001). New-Product Development in Tourism Companies - Case Studies on Nature-based Activity Operators. $10^{\text {th }}$ Nordic Tourism Research Symposium. Finland. Lane, B. (1993). Rural Tourism: a Bibliography for the OECD. Organisation of Economic Cooperation and Development. Paris.

Lane, B. (1994a). What is Rural Tourism. Journal of Sustainable Tourism, 2, 7-21.

Lane, B. (1994b). Sustainable rural tourism strategies: a tool for development and conservation. Journal of Sustainable Tourism, 2(1-2), 102-111.

Learned, E.P., Christensen, R.C., Andrews, K. R., \& Guth, W. D. (1969). Business policy: text and cases. Homewood: Irwin.

MacCannell, D. (1973). Staged Authenticity: Arrangements of Social Space in Tourist Settings. American Journal of Sociology, 79, 589-603.

Mair, H. (2006). Global restructuring and local responses: Investigating rural tourism policy in two Canadian communities. Current Issues in Tourism, 9(1), 1-45.

Mitchell, M. \& Hall, D. (2005). Rural Tourism as Sustainable Business: Key Themes. In D. Hall, I. Kirkpatrick \& M. Mitchell (Eds.) Rural Tourism and Sustainable Business. Channel View Publications.

Nepal, S.K. \& Chipeniuk, R. (2005). Mountain Tourism: Toward a Conceptual Framework. Tourism Geographies: An International Journal of Tourism Space, Place and Environment, 7(3), 313-333.

Nordregio (2004). Mountain Areas in Europe: Analysis of mountain areas in EU member states, acceding and other European countries. European Commission contract. Nordic Center for Spatial Development. Final Report.

[http://www.nordregio.se/en/Publications/Publications-2004/Mountain-areas-in-Europe/] 
Nylander, M. (2001). National policy for 'Rural Tourism': the Case of Finland. In L. Roberts \& L. Hall (Eds.) Rural tourism and recreation: principles to practice (pp. 77-85). King's Lynn: Biddles Ltd.

O’Dell, T. \& Billing, P. (2005). Experiencescapes: Tourism, culture and economy. Copenhagen: Copenhagen Business School Press.

OECD (1994). Tourism Strategies and Rural Development. Organisation for Economic Cooperation and Development. Paris. [http://www.oecd.org/industry/tourism/2755218.pdf; Accessed on 08.07.14]

OJEU (2006). Council Decision of 20 February 2006 on Community strategic guidelines for rural development (programming period 2007 to 2013). Official Journal of the European Union.

[http://eurlex.europa.eu/LexUriServ/LexUriServ.do?uri=OJ:L:2006:055:0020:0029:EN:PDF; Accessed on 08.07.14]

Okech, R., Haghiri, M., \& George, B.P. (2012). Rural Tourism as a Sustainable Development Alternative: An Analysis with special Reference to Luanda, Kenya. Cultur, 6(03), Special Issue 'Sustainability, tourism and environment in the shift of a Millennium: A peripheral view'.

Oppermann, M. (1996). Rural Tourism in Southern Germany. Annals of Tourism Research, 23(1), 86-102.

Page, S.J., \& Getz, D. (Eds.) (1997). The Business of Rural Tourism: International Perspectives (pp.3-37). Oxford: ITB.

Partalidou, M., \& Iakovidou, O. (2008). Crafting a policy framework of indicators and quality standards for rural tourism management. International Journal of Tourism Policy, 1(4), 353-367. 
Pechlaner, H., Kozak, M., \& Volgger, M. (2014). Destination leadership: A new paradigm for tourist destinations? Tourism Review, 69(1), 1-9.

Pechlaner, H., \& Volgger, M. (2012). How to promote cooperation in the hospitality industry: Generating practitioner-relevant knowledge using the GABEK qualitative research strategy. International Journal of Contemporary Hospitality Management, 24(6), 925945.

Phillip, S., Hunter, C. \& Blackstock, K. (2010). A typology for defining agritourism. Tourism Management, Vol. 3, 754-758.

Pine II, B.J. \& Gilmore, J.H. (1999). The experience economy, work is theatre and every business a stage. Boston: Harvard Business School Press.

Pröbstl I., Haider, U., Melzer, V., \& Jiricka, A. (2014). Strategies and requirements for destination leadership and rural opportunities in peripheral areas. Tourism Review (publishing in process).

Raich, M. (2008). Basic values and objectives regarding money: Implications for the management of customer relationships. International Journal of Bank Marketing, 26(1), 25-41.

Richards, G. (2002). Gastronomy. An essential ingredient in tourism production and consumption. In: Hialager, A.M. \& Richards, G. (Eds.) Tourism and Gastronomy. London, New York: Routledge.

Roberts, L., \& Hall, D. (2001). Rural Tourism and Recreation: Principles to Practice. Wallinford: CABI Publishing.

Sharpley, R. (1994). Tourism, Tourists \& Society. Huntingdon, Cambridgeshire: ELM. 
Sharpley, R. (2001). Sustainable Rural Tourism Development: Ideal or Idyll? In L. Roberts \& L. Hall (Eds.) Rural tourism and recreation: principles to practice (pp. 57-69). Wallinford: CABI Publishing.

Sharpley, R. (2002). Rural tourism and the challenge of tourism diversification: the case of Cyprus. Tourism Management, 23(3), 233-244.

Sharpley, R. \& Roberts, L. (2004). Rural Tourism - 10 Years On. International Journal of Tourism Research, 6, 119-124.

Sharpley, R. \& Sharpley, J. (1997). Rural Tourism: An Introduction. London: International Thomson Business Press.

Sharpley, R. \& Telfer, D.J. (Eds.) (2014). Tourism and Development (2nd edition): Concepts and Issues. Aspects of Tourism, Vol. 63. Channel View Publications.

Siller, L., Peters, M. and Strobl, A. (2011). Netzwerke im Kulturtourismus. Eine explorative Analyse in Südtirol. Zeitschrift für Tourismuswissenschaft, 3(1), 43-67.

Skuras, D., Petrou, A., \& Clark, G. (2006). Demand for rural tourism: the effects of quality and information. Agricultural Economics, 35, 183-192.

Snowdon, P., Slee B., \& Farr, H. (2000). The Economic Impacts of Different Types of Tourism in Upland and Mountain Areas of Europe. In P.M. Godde, M.F. Price \& F.M. Zimmermann (Eds.) Tourism and development in mountain regions (pp.137-155). Wallingford, UK: CAB International.

Stumpf, C. (1939). Erkenntnislehre: Band 1. Leipzig: Johann Ambrosius Barth.

Szabó, B. (2005). Rural Tourism as an Alternative Income Source for Rural Areas along the Hortobágy. Jahrbuch der Österreichischen Gesellschaft für Agrarökonomie, 12, 179-190.

Telfer, D.J. \& Wall, G. (1996). Linkages between Tourism and Food Production. Annals of Tourism Research, 23(3), 635-653. 
Tsephe, N.P. \& Eyono Obono, S.D. (2013). A Theoretical Framework for Rural Tourism. International Journal of Social, Management, Economics and Business Engineering, 7(1), 157-162.

UNWTO (2003). Quality in tourism. UNWTO Quality Support Committee at its sixth meeting. Varadero, Cuba, 9-10 2003 May.

[http://sdt.unwto.org/en/content/quality-tourism]

Uriely, N. (2005). The Tourist Experience. Conceptual Developments. Annals of Tourism Research, Vol. 32(1), 199-216.

Valaoras, G. (2000). Conservation and Development in Greek Mountain Areas. In P.M. Godde, M.F. Price \& F.M. Zimmermann (Eds.) Tourism and development in mountain regions (pp. 69-84). Wallingford, UK: CAB International.

Volo, S. (2009). Conceptualizing Experience: A Tourist Based Approach. Journal of Hospitality Marketing \& Management, Vol. 18(2), 111-126.

Wang, N. (1999). Rethinking authenticity in tourism experience. Annals of Tourism Research, 26(2), 349-370.

Wang, Y. (2008). Collaborative Destination Marketing. Understanding the Dynamic Process. Journal of Travel Research, 47(2), 151-166.

Weaver, G (1986). Tourism Development: A Potential for Economic Growth. In New Dimensions in Rural Policy: Building Upon our Heritage (pp. 440-444). Subcommittee on Agriculture and Transportation of the Joint Economic Committee, U.S. Congress.

Williams, F. (2001). Quality Rural Tourism, Niche Markets and Imagery: Quality Products and Regional Identity. In L. Roberts \& L. Hall (Eds.) Rural tourism and recreation: principles to practice (pp. 214-218). Wallingford: CABI Publishing. 
Wilson, S., Fesenmaier, D.R., Fesenmaier, J. and van Es, J.C. (2001). Factors for Success in Rural Tourism Development. Journal of Travel Research, 40, 132-138.

WTO (2004). Rural Tourism in Europe: Experiences, Development and Perspectives. World Tourism Organization. [http://www.idestur.org.br/download/20120219145557.pdf; Accessed on 08.07.14]

Youell, R. (2003). Integrated Quality Management in Rural Tourism. D. Hall, L. Roberts \& M. Mitchell (Eds.) New Directions in Rural Tourism (pp.169-182). London: Ashgate Publishing.

Zelger, J. (1994). Qualitative Auswertung sprachlicher Äußerungen. Wissensvernetzung, Wissensverarbeitung und Wissensumsetzung durch GABEK. In R. Wille \& $\mathrm{M}$. Zwickwolff (Eds.) Begriffliche Wissensverarbeitung: Grundfragen und Aufgaben (pp.239-266). Mannheim: B.I.-Wissenschaftsverlag.

Zelger, J. (1999). Wissensorganisation durch sprachliche Gestaltbildung im qualitativen Verfahren GABEK. In J. Zelger \& M. Mair (Eds.) GABEK. Verarbeitung und Darstellung von Wissen (pp. 41-87). Innsbruck, Wien, München: Studien-Verlag.

Zelger, J., Fink, S., \& Strickner, J. (2008). Darstellung von Erfahrungswissen durch GABEK®. In J. Zelger, M. Raich \& P. Schober (Eds.) GABEK III. Organisationen und ihre Wissensnetze. Organisations and their Knowledge Nets (pp.143-159). Innsbruck, Wien, München: Studien-Verlag. 